\title{
Career maturity, career decision-making self-efficacy and career indecision: A review of the accrued evidence
}

\author{
Authors: $\quad$ Lee-Ann Prideaux and Peter A. Creed \\ Griffith University - Gold Coast
}

Contact Address:

Dr Peter A. Creed

School of Applied Psychology

Griffith University

PMB 50, Gold Coast Mail Centre

Gold Coast 9726

Telephone: $\quad+61755528810$

Facsimile: $\quad+61755528291$

E-mail: $\quad$ p.creed@mailbox.gu.edu.au 


\title{
Career maturity, career decision-making self-efficacy and career indecision:
}

\section{A review of the accrued evidence}

\begin{abstract}
This paper reviews the recent literature on the three related career developmental constructs of career maturity, career decision-making self-efficacy and career indecision. Articles included are those published since 1990, and were generated by searching the relevant psychology and education databases. Criticisms of the usefulness and validity of the constructs are highlighted. In particular, there have been calls for the career maturity and career indecision constructs to be revised and widened. The strengths and weaknesses of the research methodology used in the three areas are also examined, and recommendations for future research are made. In all areas there is a clear need for longitudinal designs to examine these developmental constructs.
\end{abstract}

This article may not exactly replicate the final version published in the ACER journal. It is not a copy of the record. Final and authorised version first published in the Australian Journal of Career Development in 10 (2), published by the Australian Council for Educational Research. Copyright 2001 Australian Council for Educational Research. 
Career development theory building, despite its relatively short history, has established a number of well-defined constructs that are substantiated by a growing body of evidence. Three such constructs provide the focus for this paper: (a) career maturity, (b) career decision-making self-efficacy and (c) career indecision. These and other allied expressions (e.g., vocational maturity, career certainty) were used as search terms to access the appropriate research papers for this review via psychology and education databases. Reference lists from the articles obtained from this process were also inspected for relevant papers. Participant samples were not specified; thus the articles generated included college and university populations as well as high school students. Several literature reviews concentrating on each of the above constructs are already in existence and indeed, warrant attention in this paper. However, to our knowledge, the range of accumulated support for these three variables has yet to be appraised. It was our intention then to step back from the details of gathered information on these constructs and attempt to gain a big picture view of the accrued evidence. Some broad deductions are tendered in response to conjecture both about the research advances and the apparent limitations of evidence supporting each construct.

\section{Career Maturity}

Super has been very influential in the area of career development. His work, initially formulated in the early 1950s, has been widely tested, expanded, revised and refined until the present day. Portrayed as a segmental model, Super's "loosely unified set of theories" (1990; p. 199) utilises the construct of career maturity (CM), which has become one of the most prevalent variables in research involving the career development of adolescents (Powell \& Luzzo, 1998). CM is the extent to which individuals are able to make career- 
related choices independently, and was defined by Super as the "individual's readiness to cope with the developmental tasks (for) that stage of development" (1990; p. 213). It is generally accepted as comprising both cognitive and affective components.

Several assessment instruments have been constructed to measure CM. One of the most widely used, the Career Maturity Inventory (CMI; Crites, 1973), was designed to test attitudes in regard to decisiveness, involvement, independence, orientation and compromise. It also contains a competence test that assesses knowledge in terms of selfappraisal, occupational information, goal selection, planning and problem solving. The CMI, and the Career Development Inventory (CDI; Super, et al., 1988), another instrument designed to measure $\mathrm{CM}$, have acquired adequate psychometric validation to warrant their continued use (Levinson, Ohler, Caswell \& Kiewra, 1998).

Patton and Lokan (2001) presented a comprehensive report on research into the correlates of CM including age, gender, socio-economic status, culture, role salience, self-directedness, career indecision and work experience. They argued that the concept needs to be revitalized to make it "more appropriate in times of changing career patterns and more applicable to a wider range of societal groups" (p. 43). Indeed, these authors stressed the importance of contextualism as reflected by Super's original conception of the construct, joining calls from others for more consideration of this factor. They viewed such a re-formulation as the key to providing theoretical momentum for future work with the construct while also advocating the retention of its general principles.

In a special edition of the Career Development Quarterly (1998, Volume 47), Niles (1998) affirmed the role of CM in career development theory and emphasized the need to consider it within a social context. A second author (Raskin, 1998) suggested that personality and decision-making style needed to be integrated into research on CM, while 
others (Vondracek \& Reitzle, 1998; Schmitt-Rodermund \& Silbereisen, 1998) demonstrated the need for considering cultural contexts, historical determinants and economic/political structures. As a group, these authors endorsed Blustein's (1997) argument for the facilitation of exploratory skills and attitudes within a "context-rich perspective" (p. 260) to equip people "for the rather dramatic turns that may exist in travels through the life-career rainbow" (p. 272).

CM has also been criticised as a construct. Savickas (1997) argued that its fragmented structure and lack of parsimony were major weaknesses. He called for the inclusion of learning and decision-making processes into the model and the replacement of the construct of maturity with one of adaptability. Supporting this, Raskin (1998) proposed that "career adaptation is a richer, broader, developmental construct than career maturity" (p. 34).

Despite these comments, many authors continue to acknowledge the contribution of CM and apply it in their research. For example, Powell and Luzzo (1998) examined the $\mathrm{CM}$ of 253 high school students in relation to their career decision-making attributional style. This study found that those who had more personal control over their career decisions had more positive attitudes toward career decision-making and were more career aware. In another investigation using a high school sample of 1,971 Australian adolescents, Patton and Creed (2001) found developmental differences with 15-17 year olds scoring higher on CM attitude and knowledge than the 12-14 year olds. This study also revealed a complex pattern of gender differences, which led these authors to conclude "boys may benefit from increased attention to career knowledge and girls from attention to the appropriateness of career planning" (p. 349). 
At a more general level, research into $\mathrm{CM}$ and its demographic (e.g., age, gender), career (e.g., identity, career indecision) and personality correlates (e.g., self-efficacy) has been criticised as being unsystematic and poorly integrated (Patton \& Lokan, 2001). Longitudinal studies are required to augment this correlational evidence, and some equivocal findings need further investigation. For instance, an increase of CM with age has generally been demonstrated, but, for example, decision points in the educational systems have been shown to disturb maturation. Studies of CM and gender also produce inconsistent results. Females tend to score higher than males on CM, though some studies have found the opposite, and others have found no differences (see Patton \& Lokan). Lastly, there is a growing case for CM to include cultural and time-specific contexts and to have other factors, such as planning, exploration and adaptation, taken into account.

\section{Career Decision-making Self-efficacy}

Hackett and Betz (1981) were the first to apply Bandura's (1977) propositions about self-efficacy to career behaviour in a seminal study of women's career development. They demonstrated that career decisions, achievements and adjustment behaviours were subject to the influence of self-efficacy beliefs in both men and women. Taylor and Betz (1983) developed the Career Decision-making Self-efficacy (CDMSE) scale to measure these self-efficacy expectations, in terms of goal selection, occupational information, problem solving, planning, and self-appraisal. In the process, Taylor and Betz demonstrated that participants with lower levels of efficacy for decision-making were also more undecided.

Several reviews have been published on the CDMSE. Betz and Hackett (1986) focused on the use of CDMSE in clarifying "the mechanisms affecting women's 
disadvantaged status in the labor force" (p. 279). They pointed to sex-role stereotyping of particular career-related tasks as being a key determinant of gender differences in CDMSE. More recently, Betz and Luzzo (1996) reviewed the research on the CDMSE scale (both 50 and 25-item versions) and cited research attesting to their reliability, and content, criterion and construct validity. These authors also reported on a small number of counselling and educational interventions (Foss \& Slaney, 1986; Fukuyama et al., 1988; Luzzo, Funk \& Strang, 1996; Luzzo \& Taylor, 1994), which they suggested were underrepresented in an area dominated by correlational studies. They appealed for more intervention studies in order to clarify, for example, which sources of self-efficacy more readily lead to changes in CDMSE.

A large number of articles has examined the psychometric properties of the CDMSE scale (Betz, Klein \& Taylor, 1996; Gati, Osipow \& Fassa, 1994; Luzzo, 1993a, 1996a; Peterson \& delMas, 1998; Sandler, 1998). In the main, these investigations have verified the scale's strengths (based on clearly defined theory, high internal consistency, high testretest reliability), although they have generally found high inter-subscale correlations and a single general factor, meaning the CDMSE scale is best viewed as a general measure. Unfortunately, the near-exclusive use of convenience samples of college students is a weakness with these studies (Luzzo, 1996a).

A criticism of the area generally is that the research has chiefly involved correlational designs with students enrolled in introductory university courses. The correlates of CDMSE that have been examined include mathematics self-efficacy, generalized selfefficacy and global self-esteem (Betz \& Klein, 1996), environmental and self-exploration (Blustein, 1989), women's attitudes toward nontraditional occupations (Mathieu, Sowa \& Niles, 1993), underprepared college students' institutional integration (Peterson, 1993), 
college major indecision (Bergeron \& Romano, 1994), locus of control and aspirationoccupation congruence (Luzzo \& Ward, 1995), sex-role identity (Gianakos, 1995), patterns of career choice development (Gianakos, 1999), cultural differences (Mau, 2000), trait anxiety and ethnic identity (Gloria \& Hird, 1999), occupational barriers (Luzzo, 1996b), and career maturity (Luzzo, 1993b; 1994). Typically, these studies demonstrate significant relationships between CDMSE and the respective variables, and where group differences are investigated ethnic minorities and undecided participants report lower levels of CDMSE.

While this body of evidence related to young adults is impressive, there have been few studies conducted using high school participants. Brown, Darden, Shelton and Dipoto (1999) present one exception. These authors examined students' CDMSE in relation to their beliefs about career exploration, and found the latter to significantly predict CDMSE. They concluded "students' perception of the labor market and expectations of attaining career goals is related to how efficacious they feel in the implementation of career decisions" (p. 235). In another high school study, Anderson and Brown (1997) found that career development attitude was able to predict CDMSE for both rural and urban students. Lastly, Larson and Majors (1998) used factor and cluster analysis of several career-planning measures, including the CDMSE scale, to identify career indecision subtypes in 16-17 year old high school students. Two underlying dimensions were revealed (personal agency and affective distress), however, results cannot be widely generalised, as participants were those nominated as "gifted and talented".

Only six articles were identified where participants were assessed more than once. Four of these were referred to above in relation to intervention evaluations. They used pretest-posttest designs to assess the value of (a) a videotape program designed to 
broaden women's perceived career options (Foss \& Slaney, 1986), (b) a computerized career guidance program entitled DISCOVER (Fukuyama, et al., 1988), (c) the effects of verbal persuasion on career decision-making activities (Luzzo, et al., 1996) and, (d) an attributional retraining video (Luzzo \& Taylor, 1994). The fifth study was Luzzo and Day's (1999) evaluation of college students' CDMSE before and after a self-efficacy enhancing feedback session. Significant increases in CDMSE were recorded in each of the above cases. Lastly, Kraus and Hughey (1999) evaluated lessons focusing on selfappraisal, occupational information gathering, goal selection, planning and problem solving for high school students. Unfortunately, this study used a questionable design (posttest-only with delayed posttest control-group) and conclusions were difficult to draw.

To summarize, CDMSE is a well-developed construct, and the two main instruments used to measure it have been shown to exhibit sound psychometric properties. The construct has undergone rigorous examinations, albeit with a disproportionate emphasis on college samples and correlational data. It is also important to note that in every instance except two (i.e., Blustein, 1989; Kraus \& Hughey, 1999), there were marked female/male imbalances of participants, which future research should seek to amend.

\section{Career Indecision}

Like CDMSE, career indecision (CI) is closely related to the concept of CM. Super and Jordaan (1973) viewed one aspect of CM as being the ability "to make socially required career decisions" (p. 4). Consequently, CI is viewed as a developmental problem within the career maturation process "that results from a lack of information about self or the world of work" (Chartrand et al., 1994, p. 55). The assessment of CI provides 
information about the specific problems that prevent respondents from making career decisions.

The Career Decision Scale (CDS; Osipow et al., 1976) is the most widely used measure of indecision in the literature (Meier, 1991). This was developed to assess the extent and nature of $\mathrm{CI}$ as well as to provide a criterion index for the evaluation of career counselling interventions (Betz \& Voyten, 1997). It has been extensively revised and tested and has accumulated impressive validity evidence (Levinson et al., 1998). Because the original items were generated from problem statements, scores on the CDS can be analyzed to determine whether there is a need for intervention and, if so, examined to pinpoint particular concerns in terms of the career decision-making difficulties.

CI was the focus of three review papers generated by our search. First, Hall (1992) concluded that work in this area was characterized by a static and mechanistic, rather than developmental approach, and that CI was viewed as a feature of the individual rather than the outcome of a dynamic process. Hall also censured CI research for its apparent disregard of relevant career theory, and concluded that the construct needed to be broadened to include career exploration. In the second review, Osipow (1999) drew attention to the difference between indecision, classified as a normal developmental phase within the career decision-making process, and indecisiveness, which he depicted as a personal trait impinging on many decision-making situations. He cited research by Haraburda (1998), which has begun to establish the characteristics of indecisiveness that may boost "the design of interventions to deal with indecisiveness as opposed to indecision" (p. 152). Osipow also highlighted the difficulties associated with measuring these two entities, as they often look alike. He endorsed the CDMSE scale as being helpful in identifying "aspects of the career decision-making process itself in which 
clients may be deficient" (p. 152), whereas the CDS was viewed favourably as a "prepost measure to establish what, if any, changes have occurred in career indecision after counseling" (p. 150). The third review, by Osipow and Winer (1996), also had a testing focus, and catalogued the research findings using the CDS, including in the areas of gender, cross-cultural research and special populations.

Of the papers reporting individual CI studies, most again entailed measurements taken on one occasion and used undergraduate psychology students. Researchers here have identified associations between CI and task-specific self-efficacy (Temple \& Osipow, 1994), family interaction patterns (Whiston, 1996), students' perceptions of the parental relationship and career decision-making (Guerra \& Braungart-Rieker, 1999), and Kortas, Neimeryer and Prichard (1992) have initiated work on the relationship between vocational structure and participants' decision-making style. Stead and Watson (1993) factor analysed data from the CDS and other related instruments and found the former to be a unidimensional measure of indecision compared with the others that were more multidimensional. Likewise, Leong and Chervinko (1996) examined the construct validity of CI. Negative personality traits such as perfectionism and fear of commitment were found to account for up to 20 percent of the variance when CI was measured by the CDS. These authors also highlighted the two aspects of CI, as "a trait-based vocational problem" and as part of "a normative developmental process" (p. 327).

Brisbin and Savickas (1994) used the CDS, My Vocational Situation (Holland, Gottfredson \& Power, 1980) and the Career Decision Profile (Jones, 1989) to discriminate between identity status groups. Diffused and moratorium groups were successfully discriminated from identity achieved and foreclosed groups, but the authorised version first published in the Australian Journal of Career Development in 10 (2), published by the Australian Council for Educational Research. Copyright 2001 Australian Council for Educational Research. 
measures were found to be insensitive to differences in the two committed statuses (i.e., foreclosed and achieved).

One group of articles incorporated both the CDS and CDMSE scales. Taylor and Popma (1990) found a moderate negative relationship between CDMSE and CI, and identified CDMSE as the only variable to make a significant contribution to the prediction CI. Betz and Voyten (1997) also established self-efficacy beliefs as the best predictor of CI. These authors verified indecision as a significant predictor of career exploration intentions amongst women, with those less decided being more likely to make plans to undertake career search activities. Lastly, Osipow and Gati (1998) examined the construct and concurrent validity of the Career Decision-Making Difficulties Questionnaire (CDDQ; Gati, Krausz \& Osipow, 1996). These authors also found a moderate correlation between CDMSE and CI, and recommended CDDQ as a suitable adjunct to the CDS as it "enables assessment of systematic categories of difficulties... some of which are represented in the CDS... only indirectly" (p. 361).

Finally, our search produced four studies using high school students that explicitly examined results obtained from the CDS. In the first, Staley (1996) found CI was positively related to fear of success and negatively related to self-esteem. Second, CI was found to be related to identity status (Vondracek et al., 1995). Third, gender differences were found to account for 21 percent of the variance in career decision-making problems, with males perceiving greater problems than females (Rojewski \& Hill, 1998). In contrast, Patton and Creed (2001) found girls in their large sample to have higher indecision scores than boys. A fluctuating pattern of CI according to age was also revealed by these authors who concluded that "decisiveness was affected by external pressures within the school system" (p. 348). 
Despite this widespread and useful research, the mainly cross-sectional designs undermine the merit of this accrued knowledge base. The studies' inability to deal with causal relationships or interaction effects was frequently acknowledged and the critical need for longitudinal data was repeatedly stressed. Only one alternative design (Kraus \& Hughey, 1999) was identified in the present review (although this study failed to gather pre-test data). It is imperative that longitudinal designs be used on a wider variety of populations. Lastly, there have been calls for the CI construct to be expanded to give it a more process-oriented focus, for it to be viewed more positively as a temporary status within the career development course, and for it to include career "exploration" to enhance its scope.

\section{Conclusion}

It was our intention to provide a brief review of the literature on CM, CDMSE and CI, and to glean an overall impression of the accumulated evidence. We have attempted to portray the strengths and weaknesses associated with the studies in each area, and to summarize the recommendations for future research related to the constructs. In sum, the instruments commonly used to assess these variables have been shown to exhibit sound psychometric properties, and the studies involving these constructs generally attested to their value in terms of describing how career development transpires and what problems or deficiencies young people experience along the way. Furthermore, a wide range of personal and contextual variables has been identified as correlates of all three constructs.

At best, the body of evidence associated with these variables may be viewed as a firm

foundation from which more parsimonious and heuristic advancements may be launched.

It is our contention that the ultimate judgement will depend upon how subsequent 
research efforts are managed. If researchers and theorists are to heed the call for refinement of these constructs and implement more sophisticated research designs, we envisage an optimistic outcome.

The big picture view we have acquired is threefold. First, these three constructs are intimately linked, and as such may need to be investigated in unison more often. CM describes an unfolding of ability to make career related decisions; $\mathrm{CI}$ is a stumbling block within that developmental process; and CDMSE reflects the confidence to undertake these related tasks. Assertions that these three constructs are linked abound in the literature. For example, $\mathrm{CI}$ has been viewed as one of six approaches to measure $\mathrm{CM}$ (Levinson et al., 1998), and CDMSE has been considered as important in resolving career indecision (Osipow, 1999). If more research were undertaken with these aspects of career decision-making examined in unison then findings would be more comprehensive and gaps in the research field would be more limited.

Second, the constructs of $\mathrm{CM}$ and $\mathrm{CI}$ in particular require revision. Calls have been made to streamline $\mathrm{CM}$ so that it is more responsive to contextual influences. For example, Patton and Lokan (2001) reviewed research on this construct and illustrated ways in which it may evolve to become more relevant to contemporary career patterns and diverse cultures. Other suggestions for the revision of $\mathrm{CM}$ and $\mathrm{CI}$ focus on giving them a more positive slant. Career adaptability, which is the capacity to change to meet new circumstances has been proposed as a more useful conceptualization than CM. Savickas (1997), for instance, presented a strong argument for this move, stating that it "would focus counselors' attention on developing readiness to cope in clients of all ages, across all life roles" (p. 254). Likewise, CI could be couched in a more positive framework by considering it as part of "identity exploration and identity formation... 
rather than emphasizing the ultimate goal of reaching a decision" (Vondracek et al., 1995, p. 27). Hall (1992) also asserted that career exploration can be a more useful construct as "exploration can lead to trial activity, new choices, identity changes, and increased adaptability and personal agency" (p. 247).

Third, CM, CDMSE and CI need to be explored more systematically. With the advent of modern communication, researchers worldwide are now well placed to coordinate their efforts. The correlational studies that have already been undertaken need to be meticulously replicated with populations of various age groups across a diversity of cultures. Methodological designs also need improvement. Of all the studies incorporated in this review, only six were not cross-sectional. This is disturbing given the developmental nature of these constructs. Moreover, according to Hall (1992), this practice of "taking narrow slices of experiences in cross-sectional [static] terms does not do justice to the developmental process" (p. 247).

The accrued evidence for CM, CDMSE and CI is strong. However, better integration and a more sophisticated approach will enhance theory building in this area. Theoretical constructs are not intended to be immutable, but rather are expected to develop as contexts change and the body of evidence supporting them accumulates. 


\section{References}

Anderson, S., \& Brown, C. (1997). Self-efficacy as a determinant of career maturity in urban and rural high school seniors. Journal of Career Assessment, 5, 305-315.

Bandura, A. (1997). Self-efficacy: The exercise of control. New York: W. H. Freeman.

Bergeron, L. M., \& Romano, J. L. (1994). The relationships among career decisionmaking self-efficacy, educational indecision, vocational indecision, and gender. Journal of College Student Development, 35, 19-35.

Betz, N. E., \& Hackett, G. (1986). Applications of self-efficacy theory to understanding career choice behavior. Journal of Social and Clinical Psychology, 4, 279289.

Betz, N. E., \& Klein, K. L. (1996). Relationships among measures of career selfefficacy, generalized self-efficacy, and global self-esteem. Journal of Career Assessment, 4, 285-298.

Betz, N. E., Klein, K., \& Taylor, K. M. (1996). Evaluation of a short form of the Career Decision-Making Self-Efficacy scale. Journal of Career Assessment, 4, 47-57.

Betz, N. E., \& Luzzo, D. A. (1996). Career assessment and the Career DecisionMaking Self-Efficacy scale. Journal of Career Assessment, 4, 413-428.

Betz, N. E., \& Voyten, K. (1997). Efficacy and outcome expectations influence career exploration and decidedness. The Career Development Quarterly, 46, 179-189.

Blustein, D. L. (1989). The role of goal instability and career self-efficacy in the career exploration process. Journal of Vocational Behavior, 35, 194-203.

Blustein, D. L. (1997). A context-rich perspective of career exploration across the life roles. The Career Development Quarterly, 45, 260-274. 
Brisbin, L. A., \& Savickas, M. L. (1994). Career indecision scales do not measure foreclosure. Journal of Career Assessment, 2, 352-363.

Brown, C., Darden, E. D., Shelton, M. L., \& Dipoto, M. C. (1999). Career exploration and self-efficacy of high school students: Are there urban/suburban differences? Journal of Career Assessment, 7, 227-237.

Chartrand, J. M., Martin, W. F., Robbins, S. B., McAuliffe, G. J., Pickering, J. W., \& Calliotte, J. A. (1994). Testing a level versus an interactional view of career indecision. Journal of Career Assessment, 2, 55-69.

Crites, J. O. (1973). Career Maturity Inventory. Monterey, CA: McGraw-Hill/CTB.

Foss, C. J., \& Slaney, R. B. (1986). Increasing nontraditional career choices in women: Relation of attitudes toward women and responses to a career intervention. Journal of Vocational Behavior, 28, 191-202.

Fukuyama, M. A., Probert, B. S., Neimeyer, G. J., Nevill, D. D., \& Metzler, A. E. (1988). Effects of DISCOVER on career self-efficacy and decision making of undergraduates. The Career Development Quarterly, 37, 56-62.

Gati, I., Krausz, M., \& Osipow, S. H. (1996). A taxonomy of difficulties in career decision making. Journal of Counseling Psychology, 43, 510-526.

Gati, I., Osipow, S. H., \& Fassa, N. (1994). The scale structure of multi-scale measures: Application of the split-scale method to the Task-Specific Occuptional SelfEfficacy scale and the Career Decision-Making Self-Efficacy scale. Journal of Career Assessment, 2, 384-397.

Gianakos, I. (1995). The relation of sex role identity to career decision-making selfefficacy. Journal of Vocational Behavior, 46, 131-143.

Gianakos, I. (1999). Patterns of career choice and career decision-making selfauthorised version first published in the Australian Journal of Career Development in 10 (2), published by the Australian Council for Educational Research. Copyright 2001 Australian Council for Educational Research. 
efficacy. Journal of Vocational Behavior, 54, 244-258.

Gloria, A. M., \& Hird, J. S. (1999). Influences of ethnic and nonethnic variables on the career decision-making self-efficacy of college students. The Career Development Quarterly, 48, 157-174.

Guerra, A. L., \& Braungart-Rieker, J. M. (1999). Predicting career indecision in college students: The roles of identity formation and parental relationship factors. The Career Development Quarterly, 47, 255-266.

Hackett, G., \& Betz, N. E. (1981). A self-efficacy approach to the career development of women. Journal of Vocational Behavior, 18, 326-339.

Hall, D. T. (1992). Career indecision research: Conceptual and methodological problems. Journal of Vocational Behavior, 41, 245-250.

Haraburda, E. M. (1998). The relationship of indecisiveness to the five factor personality model and psychological symptomology. Unpublished doctoral dissertation, Ohio State University, Columbus, $\mathrm{OH}$.

Holland, J., Gottfredson, G., \& Power, P. (1980). Some diagnostic scales for research in decision-making and personality: Identity, information, and barriers. Journal of Personality and Social Psychology, 39, 1191-1200.

Jones, L. (1989). Measuring a three-dimensional construct of career indecision among college students: A revision of the Vocational Decision Scale - The Career Decision Scale. Journal of Counseling Psychology, 36, 477-486.

Kortas, L., Neimeyer, G. J., \& Prichard, S. (1992). Structure and style in career decision making. Journal of Career Development, 18, 199-213.

Kraus, L. J., \& Hughey, K. F. (1999). The impact of an intervention on career decision-making self-efficacy and career indecision. Professional School Counseling, 2, 
384-390.

Larson, L. M., \& Majors, M. S. (1998). Applications of the Coping with Career Indecision instrument with adolescents. Journal of Career Assessment, 6, 163-179.

Leong, F. T., \& Chervinko, S. (1996). Construct validity of career indecision: Negative personality traits as predictors of career indecision. Journal of Career Assessment, 4, 315-329.

Levinson, E. M., Ohler, D. L., Caswell, S., \& Kiewra, K. (1998). Six approaches to the assessment of career maturity. Journal of Counseling and Development, 76, 475-482.

Luzzo, D. A. (1993a). Reliability and validity testing of the Career Decision-Making Self-Efficacy scale. Measurement and Evaluation in Counseling and Development, 26, $137-142$.

Luzzo, D. A. (1993b). Value of career decision-making self-efficacy in predicting career decision-making attitudes and skills. Journal of Counseling Psychology, 40, 194199.

Luzzo, D. A. (1994, August). Assessing the value of social-cognitive constructs in career development. Paper presented at the Annual Convention of the American Psychological Association, Los Angeles, CA.

Luzzo, D. A. (1996a). A psychometric evaluation of the Career Decision-Making SelfEfficacy scale. Journal of Counseling and Development, 74, 276-282.

Luzzo, D. A. (1996b). Exploring the relationship between the perception of occupational barriers and career development. Journal of Career Development, 22, 239248.

Luzzo, D. A., \& Day, M. A. (1999). Effects of Strong Interest Inventory feedback on career decision-making self-efficacy and social cognitive career beliefs. Journal of 
Career Assessment, 7, 1-17.

Luzzo, D. A., Funk, D. P., \& Strang, J. (1996). Attributional retraining increases career decision-making self-efficacy. The Career Development Quarterly, 44, 378-386.

Luzzo, D. A., \& Taylor, M. (1994). Effects of verbal persuasion on the career selfefficacy of college freshmen. California Association for Counseling and Development Journal, 14, 31-34.

Luzzo, D. A., \& Ward, B. E. (1995). The relative contributions of self-efficacy and locus of control to the prediction of vocational congruence. Journal of Career Development, 21, 307-317.

Mathieu, P. S., Sowa, C. J., \& Niles, S. G. (1993). Differences in career self-efficacy among women. Journal of Career Development, 19, 187-196.

Mau, W. (2000). Cultural differences in career decision-making styles and selfefficacy. Journal of Vocational Behavior, 57, 365-378.

Meier, S. T. (1991). Vocational behavior, 1988-1990: Vocational choice, decisionmaking, career development interventions, and assessment. Journal of Vocational Behavior, 39, 131-181.

Niles, S. G. (1998). Special section introduction: Time and timing in career development. The Career Development Quarterly, 47, 2-3.

Osipow, S. H. (1999). Assessing career indecision. Journal of Vocational Behavior, $55,147-154$.

Osipow, S., Carney, C., Winer, J., Yanico, B., \& Koschier, M. (1976). The Career Decision Scale (Rev. 3rd ed.). Columbus, OH: Marathon Consulting and Press.

Osipow, S. H., \& Gati, I. (1998). Construct and concurrent validity of the Career Decision-Making Difficulties Questionnaire. Journal of Career Assessment, 6, 347-364. 
Osipow, S. H., \& Winer, J. L. (1996). The use of the Career Decision Scale in career assessment. Journal of Career Assessment, 4, 117-130.

Patton, W., \& Creed, P. (2001). Developmental issues in career maturity and career decision status. The Career Development Quarterly, 49, 336-351.

Patton, W., \& Lokan, J. (2001). Perspectives on Donald Super's construct of career maturity. International Journal for Educational and Vocational Guidance, 1, 31-48.

Peterson, S. L. (1993). Career decision-making self-efficacy and institutional integration of underprepared college students. Research in Higher Education, 34, 659685.

Peterson, S. L., \& delMas, R. C. (1998). The component structure of career decisionmaking self-efficacy for underprepared college students. Journal of Career Development, $24,209-225$.

Powell, D. F., \& Luzzo, D. A. (1998). Evaluating factors associated with the career maturity of high school students. The Career Development Quarterly, 47, 145-158.

Raskin, P. M. (1998). Career maturity: The construct's validity, vitality, and viability. The Career Development Quarterly, 47 , 32-35.

Rojewski, J. W., \& Hill, R. B. (1998). Influence of gender and academic risk behavior on career decision making and occupational choice in early adolescence. Journal of Education for Students Placed at Risk, 3, 265-287.

Sandler, M. E. (1998). Career decision-making self-efficacy and an integrated model of student persistence. Paper presented at the AERA Annual Meeting San Diego, CA.

Savickas, M. L. (1997). Career adaptability: An integrative construct for life-span, life-space theory. The Career Development Quarterly, 45, 247-259.

Schmitt-Rodermund, E., \& Silbereisen, R. K. (1998). Career maturity determinants: 
Individual development, social context, and historical time. The Career Development Quarterly, 47, 16-31.

Staley, W. (1996, November). The relationship between fear of success, self-concept, and career decision making. Paper presented at the Annual Meeting of the Mid-South Educational Research Association, Tuscaloosa, AL.

Stead, G. B., \& Watson, M. B. (1993). How similar are the factor structures of the Career Decision Scale, the Career Decision Profile, and the Career Factors Inventory? Educational and Psychological Measurement, 53, 281-290.

Super, D. E. (1990). A life-span, life-space approach to career development. In D. Brown, \& L. Brooks (Eds.), Career choice and development: Applying contemporary theories to practice (2nd ed., pp. 197-261). San Francisco: Jossey-Bass.

Super, D. E., \& Jordaan, J. P. (1973). Career development theory. British Journal of Guidance and Counselling, 1, 3-16.

Super, D. E., Thompson, A. S., Lindeman, R. H., Jordaan, J. P., \& Myers, R. A. (1988). Manual for the Adult Career Concerns Inventory and the Career Development Inventory. Palo Alto, CA: Consulting Psychologists Press.

Taylor, K. M., \& Betz, N. E. (1983). Applications of self-efficacy theory to the understanding and treatment of career indecision. Journal of Vocational Behavior, 22, $63-81$

Taylor, K. M., \& Popma, J. (1990). An examination of the relationships among career decision-making self-efficacy, career salience, locus of control, and vocational indecision. Journal of Vocational Behavior, 37, 17-31.

Temple, R. D., \& Osipow, S. H. (1994). The relationship between task-specific selfefficacy egalitarianism and career indecision for females. Journal of Career Assessment, Final and authorised version first published in the Australian Journal of Career Development in 10 (2), published by the Australian Council for Educational Research. Copyright 2001 Australian Council for Educational Research. 
2, 82-90.

Vondracek, F. W., \& Reitzle, M. (1998). The viability of career maturity theory: A developmental-contextual perspective. The Career Development Quarterly, 47, 6-15.

Vondracek, F. W., Schulenberg, J. E., Skorikov, V., Gillespie, L. K., \& Wahlheim, C. (1995). The relationship of identity status to career indecision during adolescence. Journal of Adolescence, 18, 17-29.

Whiston, S. C. (1996). The relationship among family interaction patterns and career indecision and career decision-making self-efficacy. Journal of Career Development, 23, 137-149.

This article may not exactly replicate the final version published in the ACER journal. It is not a copy of the record. Final and authorised version first published in the Australian Journal of Career Development in 10 (2), published by the Australian Council for Educational Research. Copyright 2001 Australian Council for Educational Research. 